\title{
Molecular tools-advances, opportunities and prospects for the control of parasites of veterinary importance
}

\author{
Sachin Kumar ${ }^{1,2} \cdot$ Snehil Gupta $^{3} \cdot$ Aquil Mohmad $^{1} \cdot$ Ashutosh Fular $^{1} \cdot$ B. C. Parthasarathi ${ }^{1} \cdot$ Ashok Kumar Chaubey $^{2}$
}

Received: 4 January 2020 / Accepted: 17 July 2020 / Published online: 29 July 2020

(C) African Association of Insect Scientists 2020

\begin{abstract}
The recent advancement in genome sequencing facilities, proteomics, transcriptomics, and metabolomics of eukaryotes have opened door for employment of molecular diagnostic techniques for early detection of parasites and determining target molecules for formulating control strategies. It further leads to the introduction of several purified vaccines in the field of veterinary parasitology. Earlier, the conventional diagnostic methods was entirely based upon morphological taxonomy for diagnosis of parasites but nowadays improved molecular techniques help in phylogenetic study and open an another area of molecular taxonomy of parasites with high precision. Control measures based upon targeting endosymbionts in parasites like Dirofilaria immitis is also under exploration in veterinary parasitology. Metagenomics have added an inside story of parasites bionomics which have created havoc in human and animals population since centuries. Omics era is playing a key role in opening the new approaches on parasite biology. Various newer generations of safer vaccines like edible vaccines and subunit vaccines and diagnostic techniques based upon purified immunologically active epitopes have become commercially available against the parasites (helminths, protozoa and arthropod borne diseases). Nowadays, a transgenic and gene knock out studies using RNA interference and CRISPR are also helping in understanding the functions of genes and screening of target genes, which are not available before the advent of molecular tools. Molecular techniques had paramount impact on increasing the sensitivity of diagnostic tools, epidemiological studies and more importantly in controlling these diseases. This review is about the advancements in veterinary parasitology and their impact on the control of these pathogens.
\end{abstract}

Keywords Veterinary parasitology $\cdot$ Parasite diagnosis $\cdot$ Molecular tools $\cdot$ Genetic resistance $\cdot$ Vaccines

\section{Introduction}

The molecular biology tools are increasingly becoming relevant to deepen the understanding of veterinary parasitology. Their implication for improvement in diagnosis and control measures against the parasites gets highlighted in last three decades due to increased ease and pace of availability of information about

Sachin Kumar

sachin.amroha@gmail.com

Ashok Kumar Chaubey

akcnema@gmail.com

1 Division of Parasitology, ICAR-Indian Veterinary Research Institute, Izatnagar, Uttar Pradesh 243122, India

2 Department of Zoology, Choudhary Charan Singh University, Meerut, Uttar Pradesh 250001, India

3 Department of Veterinary Parasitology, Lala Lajpat Rai University of Veterinary and Animal Sciences, Hisar, Haryana 125001, India parasite genomes and proteomes via various database like EuPathDB, GeneDB, WormBase, HelmCop, PathOD, EPICDB, TrypanoCyc, LeishCyc and many more such database are available on web portal (Aurrecoechea et al. 2017). It has opened new avenues to study about parasite biology, especially, at places where reasons behind their biological phenomenon were unknown. For instances, absence of maxicircle kinetoplastid DNA and its synthesized oxidative phosphorylation assembly led to adaptation of mechanical transmission by Trypanosoma evansi as a deviation from its progenitor, Trypanosoma brucei which causes nagana disease and African sleeping sickness and remain confined to African continent (Sanchez et al. 2015). Similarly, mitochondrial sequencing has brought about revolution in molecular taxonomy of parasites (Feagin 2000). It led to the merger of genera Boophilus of ixodid tick with the genera Rhipicephalus at subspecies level. Another illustration is the revised nomenclature of Babesia equi as Theileria equi due to greater phylogenetic similarity and positioning under the clade of Theileria species 
(Kappmeyer et al. 2012). Further, advancement in bioinformatics with molecular docking softwares such as Autodock, Glide, GOLD, LigandFit, QXP, Flex X, FRED, Dock and several others provides opportunity for advent of new safer and potent molecules for control of parasites (Chaudhary and Mishra 2016). Recently, drug eflorithine has introduced by target based drug identification approach against Trypanosoma brucei gambiense by targetting its Ornithine decarboxylase pathway. The Herculean task of sequencing of the complete genomes of protozoa, arthropods and parasitic helminths and their internal organisms (endosymbionts) has taken by several research groups like Sanger institute and the raw and annotated sequence are available in various genomic libraries. Polymerase chain reaction (PCR) and its variants such as multiplex PCR, Race PCR, RAPD, LAMP, nested PCR and qPCR are commonly employed to increase sensitivity and specificity of detection of parasite, identification of parasite species and strains. It can be seen by the fact that TBR and ITS-1 primer based PCR can detect as low as $0.1 \mathrm{ng}$ of the DNA of T. evansi in the whole blood (Sharma et al. 2012). Other techniques such as DNA micro-arrays, DNA probes and uniquely designed molecular beacons have greater impact in diagnostic and epidemiological studies of veterinary parasites by providing rapid screening of large number of parasite genotypes. For cloning and sequencing of genes, diagnostics and vaccines production, availability of genomic data library is a great aid for parasitologists. In addition, vaccines such as DNA vaccines and subunit vaccines have shown potential of sustained stimul ation of the host immune system compared with various recombinant protein based vaccines (). There are certain incidences where the recombinant antigen failed to produce immunity, hitherto, native antigen is highly efficacious. It can be seen in case of Barbervax which is world's first subunit vaccine against Haemonchus contortus (de Matos et al. 2017). On the other hand, Cystvax, fist cestode vaccine is entirely baed upon recombinant antigen and found highly efficacious against porcine cysticercosis (Thomas et al. 2019). Emergence of drug resistance in parasites is becoming a greater challenge for control and eradication of parasitic disease. The biotechnological tools such as pyrosequencing, allele specific PCR, PCR-RFLP and conventional PCR techniques are also involved in monitoring the development of drug resistance by targeting specific molecular markers (Kumar et al. 2020). In case of pyrethroid resistance in ticks, mutation in sodium channel gene at different location is detected (Kumar et al. 2020). Recently, point mutation in in the Theileria annulata cytochrome $\mathrm{b}$ gene is associated with buparvaquone treatment failure (Sharifiyazdi et al. 2012). Highly sensitive and specific DNA-based assays targeting resistance-alleles can provide an aid in maintaining the effectiveness of existing antiparasitic drugs and keep the parasitic diseases under control with the current available drugs. In the similar context, bulk of information are available about proteome of protozoan parasites such as Trypanosoma evansi based on nanoparticle liquid chromatography adjunct with tandem mass spectrophotometry (Roy et al. 2010). This write up will focus on diagnosis, vaccines, developments in relevant genome projects and reverse vaccinology against parasites of veterinary importance.

\section{Parasite genomics}

For diagnostic tools, vaccines and antiparasitic drugs used in controlling the pathogenic parasites, several traditional immunological studies and empirical drug screening had been carried out in veterinary parasitology but the progress achieved in terms of sensitive and specific diagnostic assays, therapeutic drugs and recombinant protein based vaccines remain lesser than expected outcome. In North-east India, there is helminth database called as Northeast India Helminth Parasite Information Database (NEIHPID) that document helminth parasite of that area, their taxonomic character alongwith information on DNA sequences of nuclear, mitochondrial and ribosomal genes marker region and next generation sequencing data for Paragonimus westermani, Fasciolopsis buski and Artyfechinostomum sufrartyfex (Biswal et al. 2016). Nowadays, there are multidirectional approaches towards research on helminth and protozoan parasites due to the availability of whole genome sequences and improvement in in vitro culture techniques. There is huge variation in size of parasites genome from size of the genomes from approximately $10 \mathrm{Mb}$ for Theileria to $270 \mathrm{Mb}$ for schistosomes. Amongst kinetoplastids, Trypanosoma brucei has a genome size of around $53 \mathrm{Mb}$ and more than 3500 random cDNA ESTs are available. Similar progress has also been made on the T.cruzi genome (Ash 1999). The sequencing and annotation of the $366 \mathrm{Mb}$ genome of Glossina morsitans morsitans is already completed long back to develop insight into African trypanosomosis (International Glossina Genome Initiative 2014). Recently, genome sequence of $L$. cuprina produced a final draft assembly of $458 \mathrm{Mb}$ which has opened new avenues for determination of drug target and vaccine candidates for control of blow fly infestation in animals (Anstead et al. $2015,2016)$. In contrast to other parasites, tick genome is highly complicated.

The Rhipicephalus microplus genome is large and complex in structure, representing over $1.8 \mathrm{~Gb}$ pairs of DNA which is stored in a database, CattleTickBase (Bellgard et al. 2012). Whole genome projects being conducted on human parasites like Brugia malayi, can benefit veterinary parasitologist while working on Dirofilaria immitis and other filarial nematodes. Similarly, information on human schistosome, Leishmania, Plasmodium and Entamoeba genome projects, will be useful for research on veterinary parasites such as Fasciola, trypanosomatid and other apicomplexan parasites. In 1996, Edna McConnell Clark Foundation has developed OnchoNET which provides series of hypertext links to the lists of available antigens, serum, genomic and cDNA libraries 
a listing of researchers currently working on onchocerciasis, which, is the fourth leading cause of blindness worldwide. Genome library serve as the basis for functional analyses of the newly discovered genes. It helps in identifying proteins that are responsible for pathogenesis, host specificity, virulence, involved in protective immune responses and those which are essential components of metabolic processes. Molecular tools such as RNA interference and CRISPR helps in confirmation of functionality of a particular gene. Genome sequencing and understanding of host parasite behavior provide the basis for designing and exploring novel antiparasitic drugs, vaccines, and diagnostic reagents. Several genomics projects on veterinary parasites like Eimeria spp., Schistosoma mansoni, Haemonchus contortus, Toxoplasma gondii and Fasciola hepatica, are either being completed or are on the verge of completion. The expanding genomic and expressed sequence tag (EST) datasets for parasitic flat worms including Schistosoma and Fasciola have helped in determining the immunogenic epitopes and aid in development of potential drugs and vaccines. As the genomes of helminth, arthropods and protozoa are relatively large in comparison to bacteria and viruses, a common strategy adopted for parasites genomics is gene finding by EST sequencing. Computational cluster analyses of ESTs reveal the relationships between many attributes, such as stage-specific genes regulation and polymorphisms between different strains of a parasite. EST analysis facilitate gene discovery, reduce redundancy and facilitate generation of consensus sequence. There is slow pace of scientific progress associated with evaluation of gene functions in parasites as not much frequently genetic manipulations are carried out on these parasites. Nowadays, functional genomics for parasitic helminths have popularized using RNA interference (RNAi) and transgene expression in several species of nematodes and trematodes for discovering their virulence factors, drug and vaccine targets. RNAi mediated gene silencing has been practiced in few nematodes like Haemonchus contortus and Ascaris suum and trematodes like Fasciola hepatica and F.gigantica (Geldhof et al. 2006). Hitherto, no RNAi-related genes like Dicer and Argonaute have been identified in Plasmodium and Leishmania species so far (McRobert and McConkey 2002; Robinson and Beverley 2003). Apart from macroscopic arthropods, ticks and insects, the mites researchers also have shown interest in gene silencing by RNAi in Dermanyssus gallinae and Sarcoptes scabiei (Kamau et al. 2013; Fernando et al. 2017).

Recently a workable and functional RNAi pathway in Fasciola hepatica was discovered (Mcgonigle et al. 2008; Rinaldi et al. 2008). In newly excysted juvenile of $F$. hepatica, the role of cathepsin-L cysteine proteinase in penetration of its host gut wall during its invasion of liver has been explored with RNAi technique (McGonigle et al. 2008). The RNAi technique has played a key role in determining the role of leucine aminopeptidases (LAPs) in the egg hatching process in the schistosomes (Rinaldi et al. 2009). Through RNAi involving functional genomic study, new opportunities could be explored such as identification of key molecules in the parasite-host interactions, future drug and vaccine targets. Therefore, in near future functional RNAi pathways will be fully explored in Schistosoma, Fasciola, ticks, protozoa to achieve the ultimate goal of development of a vaccine and therapeutic intervention for these parasites.

\section{Molecular diagnosis}

\section{Protozoa}

Protozoan parasites of veterinary significance are diagnosed conventionally by microscopy coupled either with Romanovsky stains or immunofluorescence/immunocytochemistry. Conventional techniques include the use of blood smear examination in case of haemo-protozoa (Theileria, Trypanosoma, Babesia etc.), faecal examination in case of intestinal protozoa (Giardia, Eimeria, Cryptosporidium) or tissue smears or intestinal scrapping or sections (Eimeria, Toxoplasma, Neospora) in histozoic protozoan parasites. In several laboratories, chemical test based upon alteration in serum protein and serological test based upon detection of high antibody titres in ELISA or immunofluorescence or complement fixation test (CFT) are employed as main methods for diagnosis of protozoan parasites. However, these techniques suffer from the limitation of poor sensitivity and specificity, high technical skill and large manpower requirement. With advancement in molecular techniques, there are now ranges of PCR and purified antigen-antibody based assays that are routinely used with high sensitivity, specificity and low invasiveness for diagnosis of parasitic disease. The application of microarray has raised the probability of faster detection of molecular marker of protozoan parasites (Akopyants et al. 2004). For Cryptosporidium, Babesia and Theileria, the ribosomal DNA genes have been used in PCR based genotyping and diagnostic techniques (Smith 1998; Morgan and Thompson 1998; Bashiruddin et al. 1999). Highly conserved ribosomal DNA (rDNA) genes are also useful for comparisons between closely related species. The internal transcribed spacer (ITS-1 \&2) regions are relatively small, show variability among related species and are flanked on either side by highly conserved segments to which PCR primers can be designed. Individual variations in inter-species length makes the ITS region a useful marker for identification of multiple species within a single sample (Ahmed et al. 2013). In addition, single copy sequences based PCR systems have been developed. It has been found that for the detection of Trypanosoma brucei (McNamara et al. 1994), T. vivax (Masake et al. 1997) and T. congolense (Majiwa et al. 1993), PCR based protocols are well standardized. A repetitive sequence has been well 
standardized for sensitive detection of Toxoplasma in infected tissue (Johnson et al. 1993) which is conventionally practiced by mice inoculation and hazardous Sabin Feldman dye test. PCR based techniques have been devised to detect parasite specifically from infected tissues in case of Toxoplasma and Neospora (Muller et al. 1996; Lally et al. 1996) and it has been also demonstrated that it detected as few as one parasite per milligram of muscle tissue or brain (Yamage et al. 1996). Real-time PCR is advancement in PCR techniques for quantifying the amount of original target sequence in the reaction and make it possible for estimation of the number of parasites in a given sample. With the advancement in technology, it is now possible to identify mixed species of parasites simultaneously with the help of Multiplex-PCR. In case of intestinal protozoa, multiplex real-time PCR assay was developed for the simultaneous detection of E. histolytica, G. intestinalis, and Cryptosporidium spp. in one reaction using speciesspecific probes, however, high cost limit its use in routine practices (Haque et al. 2007). Similarly, multiplex PCR developed for detection of Trypanosoma evansi and Theileria equi in equines (Sumbria et al. 2016). Multiplex PCR is also applied for the simultaneous detection of natural infection of theileriosis, babesiosis and trypanosomosis in cattle (Sharma et al. 2014; Kundave et al. 2018). In canines, detection of Babesia canis vogeli, Babesia gibsoni and Ehrlichia canis could be carried out by multiplex PCR (Jain et al. 2018). Newer techniques such as micro-arrays or molecular beacon's use in parasites of veterinary importance would be a very attractive approach. DNA micro-array technology could play an important role in raising the pace of development of diagnostics in veterinary parasitology.

\section{Helminths}

To study parasites and parasitic diseases, there has been a greater development in molecular application over the years. The advancement in application of the polymerase chain reaction (PCR) has greatly influenced the areas of parasite systematics and epidemiology, host-parasite interactions, immunology, and recombinant DNA vaccine development. The increased sensitivity of PCR has wide range of applications involving transformation of this technology not only for diagnostics, but other research areas also. Quantitative PCR is established in the concept that the amount of final PCR product can be used to conclude either the initial number of selected molecules in a given sample (quantitative PCR) or the relative starting levels of target molecules among a number of samples (relative PCR). Changes in transcription levels of the host derived selected genes (expression of cytokine genes) could be studied in interpreting the host response to the infection process.

Helminthic parasitic infection can be diagnosed through several PCR based protocols using genera and species specific primers. This may be followed by restriction fragment length polymorphism (RFLP), PCR-linked single strand conformation polymorphism (SSCP) and PCR linked to hybridization with specific probes as more confirmatory tools for diagnosis of the parasite species, isolates / strains. Also, for discovering the polymorphism in the parasite, random amplified polymorphic DNA (RAPD) based on non-specific primers is a useful tool.

DNA- based assays based on ribosomal DNA sequences such as internal transcribed spacers (ITS-1 and ITS-2), $28 \mathrm{~s}$, $16 \mathrm{~s}, 18 \mathrm{~s}$ and mitochondrial sequences are species specific and provide a DNA region which allows for high sensitivity and specificity for parasitic helminths (Huang et al. 2004). Using this technique with the second ITS spacer (ITS-2), helminth such as Haemonchus, Cooperia, Nematodirus, Trichostrongylus and Ostertagia genera were differentiated and detected based on single egg (Schnieder et al. 2010). Different strains within a parasitic species have been differentiated successfully based on DNA-based assays (Zarlenga et al. 1999) and to evaluate biological differences between them. Using ITS-PCR, differences in pre-patent periods between different isolates of Oesophagostomum was also studied (Talvik et al. 1997). The strain/genotype identification in Echinococcus for determining host specificity has been made possible with PCR and sequencing techniques. In fact, PCR has become a crucial molecular assay in the studies on helminth parasites of veterinary importance in their genotyping, strain, diagnosis, identification and providing DNA for promoting recombinant antigens for vaccine development.

\section{Vaccine development}

\section{Protozoa}

Live attenuated vaccines are available in case of Babesia bovis (Callow et al. 1997), Eimeria spp. (Shirley and Bedrnik 1997), Toxoplasma (Buxton et al. 1991) and Theileria annulata (Pipano 1995), however, they suffer from certain disadvantages such as possibility of contamination with other pathogens, need of a cold chains for maintenance of efficacy, tedious production, reversion to pathogenic forms and low shelf life. With the advancement in molecular biology, there are certain sub-unit vaccines in existence for Leishmania, Plasmodium and Eimeria species.

While our knowledge of protective immune mechanisms involved in B. bigemina and B. bovis infections is not complete, it is clear that antibody plays a significant role (Mahoney 1986) and there is greater proof for a notable role for CD4 + T-cells and activated macrophages (Brown and Palmer 1999). Systematic testing of fractionated B. bovis merozoite proteins have resulted in identification of several antigens that conferred a level of protection to vaccinated animals (Wright et al. 1992). Under field conditions, combinations of 
these antigens, tested gave notable protection as well as protection levels close to those provided by the live vaccine. A set of antigens have been identified using CD4 + T-cell screening (Jasmer et al. 1992; Hines et al. 1992; Brown et al. 1996) that include a set of spherical body antigens (SBPs) and two major merozoite surface antigens that are secreted by the parasite and located on the cytoplasmic face of the red blood cell (Dowling et al. 1996). T-cell epitopes mapped for rhoptry protein RAP-1 are considered as a major candidate antigen for inclusion a sub-unit vaccine (Brown et al. 1996, 1998). RAP-1 proteins in B. bigemina immunization manifest a protective effect on challenge, however, only reduction in parasitaemia and no complete protection occurs (Brown et al. 1998; McElwain et al. 1991). Research on the development of a sub-unit vaccine against $T$. annulata and Theileria parva has concentrated on the clarification of the mechanisms of immunity and the isolation of surface antigens and their characterization as they are found to be predominant in host cell invasion. Moreover, the protective immune response to T. parva is because of a major role for cytotoxic T-cells (McKeever et al. 1994) with parasite peptides presented on MHC Class I molecules of infected lymphocytes acting as the target that mediates their lysis (McKeever et al. 1999). The protective response to $T$. annulata involves a complex interplay between activated macrophages, NK cells, and cytotoxic T-cells (Preston et al. 1999; Boulter and Hall 2000). Moreover, the humoral response has a little role in intracellular parasites infected animals. The laboratory based immunization trails of major sporozoite surface antigen (SPAG) from both species has been used as recombinant antigen (Boulter et al. 1995, 1998; Morrison and McKeever 1998), with a covering a protective response up to $70 \%$ in T. parva (Musoke et al. 1992) and notable decrease in a number of disease parameters including parasitaemia with $T$. annulata (Boulter and Hall 2000). The recombinant SPAG-1 protein delivered with RWL showed better protection against challenge than when delivered with ISCOMS (Boulter et al. 1998, 1999). d'Oliveira et al. (1997) expressed these proteins in E.coli using gene fragments lacking both hydrophobic domains to assess the potential of these molecules for use in diagnosis and as components in a multi-unit recombinant vaccine.

Sequence analysis of the many alleles of Tams has shown that they encode the highly polymorphic molecules, particularly within a region that contains a number of putative $\mathrm{N}$ linked glycosylation sites (Katzer et al. 1998). It is postulated that this level of antigenic diversity may indicate selection of variable glycosylation sites or amino acid epitopes in order to evade the host immune response (Shiels et al. 1995). For a sub unit vaccine to be successful; it requires the inclusion of antigens that stimulate cellular responses to the schizont infected lymphocytes. Approaches to the identification of such molecules are being developed and include (T. parva) the elution of peptides from MHC Class I molecules to evaluate their ability to sensitize target cells to cytotoxic T-cell killing (McKeever et al. 1999). Along with identification of active molecules, the problem of antigen delivery needs to be checked.

\section{Arthropods of Veterinary and Medical Importance}

Arthropods such as ticks, mites, flies, bugs and lice are responsible for both direct and indirect losses to the livestock industry. Next to the chemotherapy using ecto-parasiticidal and repellant agent, major thrust of the researchers is to establish a sustainable immunological control of arthropods by development of suitable vaccines. In this direction, major work in veterinary parasitology is carried out on the control of one host tick, Rhipicephalus microplus. Vaccine against the tick Rhipicephalus microplus is based on successful recombinant antigens commercialised in market (Tick GARD Plus in Australia and GAVAC Plus in Cuba). Later, Tick GARD Plus was withdrawn by Australian government due to low economic return; however, it is still continued in Cuba. This vaccine contains concealed immunogenic mid gut antigens (Bm86, Bm91) and vaccination leads to decrease in the number of engorged females, increased red ticks due to bursting of mid gut and the reduction up to $90 \%$ in the number of larvae per generation (Willadsen and Jongejan 1999). Initially, studies on tick immunological control address mostly singleantigen vaccines. However, so far no single-antigen vaccine has afforded appropriate protection against all $R$. microplus populations, therefore, new modified vaccines were launched but they were also proven ineffective in other countries due to strain variation. In this context, to enhance vaccine efficacy, multi-antigen cocktails are evolving as a novel methodology in tick control strategies. Moreover, to have a protective immune responses against heterologous tick challenges, coomon situation in tropical countries like India, identification and development of a universal anti-tick vaccine such as based on salivary antigen like aquaporin or structural component of body like cystatin and any other combination involving one or more common tick antigens and would be economically and technically attractive. Also, the finding of an antigenic protein conserved between ticks and mosquitoes (Canales et al. 2009; Prudencio et al. 2010) have increased the possibility of a pan-arthropod vaccine. The development of a universal vaccine could depend on highly conserved tick proteins with narrow and reasonable antigenic variations, which are capable of involving in a protective cross-reactive immunity against different tick species (Parizi et al. 2012a, b).

Fly menace is another major problem globally, especially, in tropical and subtropical part of world. Few researchers are attracted towards immunological control for mitigating the losses due to flies in livestock industry. There is advancement observed in vaccine development against Culicoides, Lucilia and Hypoderma flies. Insect-bite hypersensitivity (IBH) in horses is manifested by chronic relapsing seasonal allergic 
dermatitis and is mainly caused by the biting of Culicoides flies. IBH is a IgE-dependent type I allergy, with a strong involvement of type $\mathrm{IVb}$ allergic hypersensitivity reactions in dermatitis resulting into recruitment of eosinophils into the allergic site. Type IVb allergy is associated with IL-5 producing $\mathrm{TH} 2$ cells, eosinophilia, and eosinophil accumulation in perivascular clusters in deeper parts of the dermis. Eosinophil development in the bone marrow and release and activation in blood circulation is mediated by IL-5. Mice either vaccinated against murine IL-5 or IL-5-deficient (knockout) mice showed strongly reduced levels of blood eosinophils and eosinophil-mediated inflammation. Furthermore, anti-IL-5 $\mathrm{mAb}$, significantly reduced circulating eosinophil. Gabriel and coworkers (Fettelschoss-Gabriel et al. 2018) targetted IL-5 for mitigating the allergic reaction in equines due to bite of Culicoides flies. Targeting IL-5 with mAbs is not a realistic approach in equines due to large weight and corresponding high dosages. Recently, a novel VLP platform has been developed based on the cucumber mosaic virus containing the tetanus toxoid universal T-cell epitope tt830-843 (CMVTT) to enhance TH cell-dependent IgG responses for antigens displayed on its surface. Accordingly, a vaccine consisting of equine IL-5 (eIL-5) chemically linked to CMVTT-VLPs has found to induces potent anti-eIL-5 antibody responses, which improve symptoms of IBH in horses. A second vaccine using the same CMVTT VLP backbone but targeting equine IL- 31 was tested by the same group of researchers. IL-31 is a Th2 cell cytokine that interacts with the nervous system via the IL-31 receptor expressed by dorsal root ganglia cells in the skin and triggers the allergic pruritus (Sonkoly et al. 2006; Mizuno et al. 2009). In IBH, IL-31 was found to be exclusively expressed in punch biopsies of IBHaffected skin lesions (Olomski et al. 2020). Further, studies including larger patient cohorts and combining both IL-5 and IL31 vaccines may elucidate significant benefit of the vaccines in IBH-affected horses (Jonsdottir et al. 2019).

Peritrophic membrane (PM) lines the gut of many arthropods and separates ingested food from the gut epithelium. PM restrict the penetration of ingested immune effector components $\mathrm{f}$ host and in other ways, it can serve as a target for immunological attack of host. Sheep vaccinated with extracts of PM from larvae of the sheep blowfly, Lucilia cuprina, slowed the growth of L. cuprina larvae (Eisemann and Binnington 1994). In a another study, a mucin-like glycoprotein, peritrophin-55, isolated and purified from $L$. cuprina larvae inhibited larval growth by $51-66 \%$ when larvae fed on sera from the vaccinated sheep (Tellam et al. 2003). The situation with another myiasis fly, C. bezziana is also similar on vaccination with $\mathrm{Cb} 15, \mathrm{Cb} 42$ and $\mathrm{Cb} 48$ antigens. Vaccination of sheep leads to dramatic reduction in the weight of larvae recovered from both in vitro and in vivo assay systems. Fractionation, characterisation and expression of a number of peritrophic membrane proteins have proven to be ineffective so far (Sukarsih Partoutomo et al. 2000).

\section{Helminths}

Great successes had been achieved against bacterial and viral pathogens related to vaccine, but little success has been achieved against eukaryotic parasites due to similar cellular machinery. There are fewer number of successful anti-parasite helminth vaccines developed, however, until recently all were based on the use of living, attenuated parasites. Examples are the vaccines against tropical theileriosis (Pipano 1995), babesiosis (Callow et al. 1997), and lungworm in cattle (Jarret et al. 1960), sheep and goat (Dhar and Sharma 1981), ovine nodular worm (Dhar and Sharma 1980), canine hookworm, Ancyclostoma caninum vaccine (Miller 1978) and coccidiosis in chickens (Shirley and Badrnik 1997). With the beginning of molecular era, recombinant antigen based vaccine comes into existence. World first cestode vaccine, Cysvax is commercialized by Indian immunological to curtail the case of porcine cysticercosis. Similarly, Barbervax vaccine was launched for the control of Haemonchus contortus in sheep, hitherto, it is a native antigen based vaccine and large scale production rely upon slaughter house availability. These vaccines antigens were identified, confirmed and produced using recombinant DNA approaches, after doing immunochemical analysis with the help of molecular tools. The recombinant vaccines against cysticercosis and hydatidosis in sheep and cattle have long been developed, but away from commercialization due to poor market response. Moreover, three highly immunogenic oncosphere antigens have been identified from Taenia ovis (To 45W, To16.17 and To18) and expressed recombinantly, and it produced 73-99\% protection in sheep challenged with T. ovis (Harrison et al. 1996). Similar, high levels of protection have been found against $T$. saginata (Tsa 9 and Tsa 18) in cattle (99\%) with recombinant oncosphere antigens (Lightowlers et al. 1996a, b) have shown protection against T. solium (To 45W, To 16.17 and To 18 derived from T. ovis) in pigs (93\%) (Plancarte et al. 1999) and E. granulosus (EG 95) in sheep (97\%) (Lightowlers et al. 1996a, b). Further, glutathione-S-transferase (GST), fatty acid binding protein (FABP) and cathepsin L1 and L2 and hafve been explored in vaccination studies against $F$. hepatica and $F$. gigantica in sheep and cattle. However, moderate level of protection against worm numbers has been found. A potential vaccine candidate, $F$. hepatica leucine aminopeptidase (LAP) has shown significant protective efficacy $\geq 85 \%$ against a challenge infection by $F$. hepatica in sheep (Maggioli et al. 2011). Commercialization of these vaccines could lead to a breakthrough in veterinary parasitology.

Since the commercialization of a recombinant vaccine against the Australian cattle tick, Rhipicephalus (Boophilus) microplus (Willadsen et al. 1995), substantial work has been done on "concealed antigens" in nematode parasites. Medium to strong levels of protection have been recorded in sheep vaccinated with $H$. contortus gut aminopeptidases 'H11' 
(Smith et al. 1997). Other antigen, H-gal-GP, a glycoprotein complex containing predominantly digestive proteases, is a promising vaccine molecule (Ekoja and Smith 2010). Other proteins of $H$. contortus which are of interest for vaccine development are an extensive family of cathepsin B-like cysteine proteases (Rehman and Jasmer 1999), glutamate dehydrogenase (Skuce et al. 1999), $\mathrm{Cu} / \mathrm{Zn}$ superoxide dismutases (Liddell and Knox 1998), etc. As the whole genome sequencing of pathogenic helminths such as $H$. contortus $(370 \mathrm{Mb})$ has been completed (Laing et al. 2013), this will likely increase the process of development of highly effective antinematode vaccines.

\section{Reverse vaccinology}

The field of reverse vaccinology developed is an outcome of the genome sequence revolution. Vaccine candidates for control of theileriosis, leishmaniasis, malaria, schistosomiasis, anaplasmosis and the cattle tick have been identified using reverse vaccinology approaches (Lew-tabor and Valle 2016). Reverse vaccinology (RV) involves use of bioinformatics analysis of genome sequence data along with the laboratory screening to identify new vaccine candidate (Rappuoli 2000). It involves new approach of not involving a pathogen to be cultivated for discovery of vaccine. For vaccine design, computers are used and no live organism is involved. It provides all the protein antigens that a pathogen can express at any time by genome sequence analysis. This approach was used in small genomes pathogens and resulted in the first successful vaccine produced against meningititis and sepsis causing bacteria (type B Neisseria meningitidis) in children and young (Adu-Bobie et al. 2003; Rappuoli 2000). Reverse vaccinology approaches for eukaryotes have also recently been used but that describes the detail study of vaccine candidate identification and not the approach applied (Schubert-Unkmeir and Christodoulides 2013). For many parasites species including Schistosoma (Wang et al. 2016), Cryptosporidium (Manque et al. 2011), Toxoplasma (Sette and Rappuoli 2010), Giardia and Trichomonas (Aslett et al. 2009) many databases 'omic' and EST have evolved with the arrival of more genome sequences. In an in silico study of Neospora caninum using RV approach, several potential vaccine candidates are shortlisted and ranked (Goodswen et al. 2017). For the parasites, RV approach had not yet produced any commercialised products. Protozoan genome based RV approach for the genus Leishmania was developed (Rezende et al. 2012). For parasite (protozoa) and veterinary vaccines such as coccidiosis, the databases and in silico tools for vaccine design have kept evolving for example, VIOLIN-Vaccine Investigation and Online Information Network. (He et al. 2013; He and Xiang 2013). Recently, RV approach was used for identification and characterization of Ctenocephalides felis protective antigens for the control of cat flea infestations (Contreras et al. 2018).

\section{Conclusions}

Genome information on arthropods, protozoa and helminths opens up new understanding on parasite biology and advanced approaches for improving diagnosis and control measures. DNA micro-arrays can help in exploring the new knowledge of parasite genomes. Host-parasite interactions and parasite immune evasion mechanisms understanding will lead to the development of successful vaccines. Using knowledge and tools of molecular biology and bioinformatics in teaching, research, and clinical work will accelerate the expansion of vaccines, diagnostics and newer anti-parasitic drugs for controlling the risk of parasitism in our livestock. The multivalent molecules developed for bacterial vaccines using reverse vaccinology approaches can act as key for future parasite vaccine development.

Acknowledgements The authors are grateful to the Indian Council of Medical Research (ICMR) Project grant number (2019-3686) and also thankful to Department of Science and Technology -Science and Engineering Research Board, Government of India, New Delhi

\section{Compliance with ethical standards}

Conflict of interest The authors declared that there is no conflict of interest among them.

\section{References}

Adu-Bobie J, Capecchi B, Serruto D, Rappuoli R, Pizza M (2003) Two years into reverse vaccinology. Vaccine 21(7-8):605-610

Ahmed HA, Picozzi K, Welburn SC, MacLeod ET (2013) A comparative evaluation of PCR-based methods for species-specific determination of African animal trypanosomes in Ugandan cattle. Parasites Vectors 6(1):316

Akopyants NS, Matlib RS, Bukanova EN, Smeds MR, Brownstein BH, Stormo GD, Beverley SM (2004) Expression profiling using random genomic DNA microarrays identifies differentially expressed genes associated with three major developmental stages of the protozoan parasite Leishmania major. Mol Biochem Parasit 136(1):7186

Anstead CA, Batterham P, Korhonen PK, Young ND, Hall RS, Bowles VM, Richards S, Scott MJ, Gasser RB (2016) A blow to the flyLuciliacuprina draft genome and transcriptome to support advances in biology and biotechnology. Biotechnol Adv 34(5):605-620

Anstead CA, Korhonen PK, Young ND, Hall RS, Jex AR, Murali SC, Hughes DS, Lee SF, Perry T, Stroehlein AJ, Ansell BR (2015) Luciliacuprina genome unlocks parasitic fly biology to underpin future interventions. Nat Commun 6(1):7344

Ash C (1999) Exploring parasite genomes. Trends in microbiology 7(1): $10-12$

Aslett M, Aurrecoechea C, Berriman M, Brestelli J, Brunk BP, Carrington M, Depledge DP, Fischer S, Gajria B, Gao X, Gardner MJ (2009) TriTrypDB: a functional genomic resource for the Trypanosomatidae. Nucleic Acids Res 38:D457-D462

Aurrecoechea C, Barreto A, Basenko EY, Brestelli J, Brunk BP, Cade S, Crouch K, Doherty R, Falke D, Fischer S, Gajria B (2017) EuPathDB: the eukaryotic pathogen genomics database resource. Nucleic Acids Res 45(D1):D581-D591 
Bashiruddin JB, Camma C, Rebêlo E (1999) Molecular detection of Babesia equiand Babesia caballiin horse blood by PCR amplification of part of the 16S rRNA gene. Vet Parasitol 84:75-83

Bellgard MI, Moolhuijzen PM, Guerrero FD, Schibeci D, RodriguezValle M, Peterson DG, Dowd SE, Barrero R, Hunter A, Miller RJ, Lew-Tabor AE (2012) Cattle TickBase: an integrated Internet-based bioinformatics resource for Rhipicephalus (Boophilus) microplus. Int J Parasitol 42(2):161-169

Biswal DK, Debnath M, Kharumnuid G, Thongnibah W, Tandon V (2016) Northeast India Helminth Parasite Information Database (NEIHPID): Knowledge Base for Helminth Parasites. PLoS One 11(6)

Boulter NR, Brown CG, Kirvar E, Glass E, Campbell J, Morzaria S, Nene V, Musoke A, d'Oliveira C, Gubbels MJ, Jongejan F, Hall FR (1998) Different vaccine strategies used to protect against Theileria annulata. Ann NY Acad Sci 849:234-246

Boulter N, Brown D, Wilkie G, Williamson S, Kirvar E, Knight P, Glass E, Campbell J, Morzaria S, Nene V, Musoke A, d'Oliveira C, Gubbels MJ, Jongejan F, Hall R (1999) Evaluation of recombinant sporozoite antigen SPAG-1 as a vaccine candidate against Theileria annulata by the use of different delivery systems. Trop Med Int Health 4:A71-A77

Boulter NR, Glass EJ, Knight PA, Bell-Sakyi L, Brown CG, Hall R (1995) Theileria annulata sporozoite antigen fused to hepatitis B core antigen used in a vaccination trial. Vaccine 13:1152-1160

Boulter NR, Hall FR (2000) Immunity and vaccine development in bovine theilerioses. Adv Parasitol 44:41-97

Brown WC, McElwain TF, Hotzel I, Ruef BJ, Rice-Ficht AC, Stich RW, Suarez CE, Estes DM, Palmer GH (1998) Immunodominant T-cell antigens and epitopes of Babesia bovisand Babesia bigemina. Ann Trop Med Parasitol 92:473-482

Brown WC, McElwain TF, Ruef BJ, Suarez CE, Shkap V, ChitkoMcKown CG, Tuo W, Rice-Ficht AC, Palmer GH (1996) Babesia bovisrhoptry-associated protein-1 is immunodominant for T-helper cells of immune cattle and contains T-cell epitopes conserved among geographically distant B. bovisstrains. Infect Immun 64: 3341-3350

Brown WC, Palmer GH (1999) Designing blood-stage vaccines against Babesia bovisand B. bigemina. Parasitol Today 15:275-281

Buxton D, Thomson K, Maley S, Wright S, Bos HJ (1991) Vaccination of sheep with a live incomplete strain (S48) of Toxoplasma gondiiand their immunity to challenge when pregnant. Vet Record 129:89-93

Callow LL, Dalgliesh RJ, Vos AJ de (1997) Development of effective living vaccines against bovine babesiosis the longest field trial. Int $\mathrm{J}$ Parasitol 27:747-767

Canales M, Naranjo V, Almazan C, Molina R, Tsuruta SA, Szabo MPJ, Manzano-Roman R, de la Lastra JMP, Kocan KM, Jimenez MI, Lucientes J, Villar M, de la Fuente J (2009) Conservation and immunogenicity of the mosquito ortholog of the tick-protective antigen, subolesin. Parasit Res 105:97-111

Chaudhary KK, Mishra N (2016) A review on molecular docking: novel tool for drug discovery. Databases 3(4)

Contreras M, Villar M, Artigas-Jerónimo S, Kornieieva L, Mytrofanov S, de la Fuente J (2018) A reverse vaccinology approach to the identification and characterization of Ctenocephalidesfelis candidate protective antigens for the control of cat flea infestations. Parasites Vectors 11(1):43

d'Oliveira C, Feenstra A, Vos H, Osterhaus AD, Shiels BR, Cornelissen AW, Jongejan F (1997) Induction of protective immunity to Theileria annulata using two major merozoite surface antigens presented by different delivery systems. Vaccine 15:1796-1804

de Matos AFIM, Nobre COR, Monteiro JP, Bevilaqua CML, Smith WD, Teixeira M (2017) Attempt to control Haemonchuscontortus in dairy goats with Barbervax ${ }^{\circledR}$, a vaccine derived from the nematode gut membrane glycoproteins. Small Rumin Res 151:1-4
Dhar DN, Sharma RL (1981) Immunization with irradiated larvae against Dictyocaulusfilaria in young lambs. Vet Parasitol 9(2):125-131

Dowling SC, Perryman LE, Jasmer DP (1996) A Babesia bovis225-kDa spherical body protein: localization to the cytoplasmic face of infected erythrocytes after merozoite invasion. Infect Immun 64:26182626

Eisemann CH, Binnington KC (1994) The peritrophic membrane: its formation, structure, chemical composition and permeability in relation to vaccination against ectoparasitic arthropods. Int J Parasitol 24(1):15-26

Ekoja SE, Smith WD (2010) Antibodies from sheep immunised against Haemonchuscontortuswith H-gal-GP inhibit the haemoglobinase activity of this protease complex. Parasite Immunol 32:731-738

Feagin JE (2000) Mitochondrial genome diversity in parasites. Int J Parasitol 30(4):371-390

Fernando DD, Marr EJ, Zakrzewski M, Reynolds SL, Burgess ST, Fischer K (2017) Gene silencing by RNA interference in Sarcoptesscabiei: a molecular tool to identify novel therapeutic targets. Parasites Vectors 10(1):289

Fettelschoss-Gabriel A, Fettelschoss V, Thoms F, Giese C, Daniel M, Olomski F, Zeltins A (2018) Treating insect-bite hypersensitivity in horses with active vaccination against IL-5. J Allergy Clin Immunol 142(4):1194-1205

Geldhof P, Visser A, Clark D, Saunders G, Britton C, Gilleard J, Berriman M, Knox D (2006) RNA interference in parasitic helminths: current situation, potential pitfalls and future prospects. Parasitol 134(5):609-619

Goodswen SJ, Kennedy PJ, Ellis JT (2017) On the application of reverse vaccinology to parasitic diseases: a perspective on feature selection and ranking of vaccine candidates. Int J Parasitol 47(12):779-790

Haque R, Roy S, Siddique A, Mondal U, Rahman SM, Mondal D, Houpt E, Petri WA Jr (2007) Multiplex real-time PCR assay for detection of Entamoebahistolytica, Giardia intestinalis, and Cryptosporidium spp. Am J Trop Med Hyg 76(4):713-717

Harrison GB, Heath DD, Dempster RP, Gauci C, Newton SE, Cameron WG, Robinson CM, Lawrence SB, Lightowlers MW, Rickard MD (1996) Identification and cDNA cloning of two novel low molecular weight host-protective antigens from Taenia ovis oncospheres. Int $\mathrm{J}$ Parasitol 26:195-204

He Y, Racz R, Sayers S, Lin Y, Todd T, Hur J, Li X, Patel M, Zhao B, Chung M, Ostrow J (2013) Updates on the web-based VIOLIN vaccine database and analysis system. Nucleic Acids Res 42(D1): 1124-1132

Hines SA, Palmer GH, Jasmer DP, McGuire TC, McElwain TF (1992) Neutralisation sensitive merozoite surface antigens of Babesia bovisencode members of a polymorphic gene family. Mol Biochem Parasitol 55:85-94

Huang WY, He B, Wang CR, Zhu XQ (2004) Characterisation of Fasciola species from Mainland China by ITS-2 ribosomal DNA sequence. Vet Parasitol 120:75-83

International Glossina Genome Initiative (2014) Genome sequence of the tsetse fly (Glossinamorsitans): vector of African trypanosomiasis. Science 344(6182):380-386

Jain J, Lakshmanan B, Nagaraj HV, Praveena JE, Syamala K, Aravindakshan T (2018) Detection of Babesia canisvogeli, Babesia gibsoni and Ehrlichiacanis by multiplex PCR in naturally infected dogs in South India. Veterinarski Arhiv 88(2):215-224

Jarret WFH, Jenning FW, McIntyre WIM, Mulligan W, Urquhart GM (1960) Immunological studies on Dictyocaulusviviparus infection. Immunity produced by the administration of irradiated larvae. Immunology 3:145-151

Jasmer DP, Reduker DW, Hines SA, Perryman LE, McGuire TC (1992) Surface epitope localisation and gene structure of a Babesia bovis44 kDa variable merozoite surface protein. Mol Biochem Parasitol 55:75-84 
Johnson JD, Butcher PD, Savva D, Holliman RE (1993) Application of the polymerase chain reaction to the diagnosis of human toxoplasmosis. J Infect 26:147-158

Jonsdottir S, Cvitas I, Svansson V, Fettelschloss-Gabriel A, Torsteinsdottir S, Marti E (2019) New Strategies for Prevention and Treatment of Insect Bite Hypersensitivity in Horses. Curr Dermatol Rep 8(4):303-312

Kamau LM, Wright HW, Nisbet AJ, Bowman AS (2013) Development of an RNA-interference procedure for gene knockdown in the poultry red mite, Dermanysusgallinae: studies on histamine releasing factor and Cathepsin-D. Afr J Biotechnol 12(12)

Kappmeyer LS, Thiagarajan M, Herndon DR, Ramsay JD, Caler E, Djikeng A, Gillespie JJ, Lau AO, Roalson EH, Silva JC, Silva MG (2012) Comparative genomic analysis and phylogenetic position of Theileria equi. BMC Genom 13(1):603

Katzer F, McKellar S, Ben Miled L, D’Oliveira C, Shiels B (1998) Selection for antigenic diversity of Tams1, the major merozoite antigen of Theileria annulata. Ann N Y Academy of Science 849: 96-108

Kumar R, Sharma AK, Ghosh S (2020) Menace of acaricide resistance in cattle tick, Rhipicephalus microplus in India: Status and possible mitigation strategies. Vet Parasitol 278:108993

Kundave VR, Ram H, Banerjee PS, Garg R, Mahendran K, Ravikumar GVPPS, Tiwari AK (2018) Development of multiplex PCR assay for concurrent detection of tick borne haemoparasitic infections in bovines. Actaparasitol 63(4):759-765

Laing R, Kikuchi T, Martinelli A, Tsai IJ, Beech RN, Redman E, Holroyd N, Bartley DJ, Beasley H, Britton C, Curran D (2013) The genome and transcriptome of Haemonchuscontortus, a key model parasite for drug and vaccine discovery. Genome Biol 14(8):R88

Lally NC, Jenkins MC, Dubey JP (1996) Development of a polymerase chain reaction assay for the diagnosis of neosporosis using the Neosporacaninum14-3-3 gene. Mol Biochem Parasitol 75:169-178

Lew-Tabor AE, Valle MR (2016) A review of reverse vaccinology approaches for the development of vaccines against ticks and tick borne diseases. Ticks Tick Borne Dis 7(4):573-585

Liddell S, Knox DP (1998) Extracellular and cytoplasmic Cu/Zn superoxide dismutases from Haemonchus contortus. Parasitol 116:383394

Lightowlers MW, Lawrence SB, Gauci CG, Young J, Ralston MJ, Maas D, Health DD (1996a) Vaccination against hydatidosis using a defined recombinant antigen. Parasite Immunol 18:457-462

Lightowlers MW, Rolfe R, Gauci CG (1996b) Taeniasaginata: vaccination against cysticercosis in cattle with recombinant oncosphere antigens. Exp Parasitol 84:330-338

Maggioli G, Acosta D, Silveira F, Rossi S, Giacaman S, Basika T, Gayo V, Rosadilla D, Roche L, Tort J, Carmona C (2011) The recombinant gut-associated M17 leucine aminopeptidase in combination with different adjuvants confers a high level of protection against Fasciola hepatica infection in sheep. Vaccine 29:9057-9063

Mahoney DF (1986) In: Morrison WI (ed), The Ruminant Immune System in Health and Disease. Cambridge University Press, Cambridge, pp 539-545

Majiwa PA, Maina M, Waitumbi JN, Mihok S, Zweygarth E (1993) Trypanosoma (Nannomonas) congolense: molecular characterization of a new genotype from Tsavo, Kenya. Parasitol 106:151-162

Manque PA, Tenjo F, Woehlbier U, Lara AM, Serrano MG, Xu P, Alves JM, Smeltz RB, Conrad DH, Buck GA (2011) Identification and immunological characterization of three potential vaccinogens against Cryptosporidium. Clin Vaccine Immunol CVI-05197

Masake RA, Majiwa PAO, Moloo SK, Makau JM, Njuguna JT, Maina M, Kabata J, ole-MoiYoi OK, Nantulya VM (1997) Sensitive and specific detection of Trypanosoma vivax using the polymerase chain reaction. Exp Parasitol 85(2):193-205

McElwain TF, Perryman LE, Musoke AJ, McGuire TC (1991) Molecular characterization and immunogenicity of neutralization-sensitive
Babesia bigemina merozoite surface proteins. Mol Biochem Parasitol 47:213-222

McGonigle L, Mousley A, Marks NJ, Brennan GP, Dalton JP, Spithill TW, Day TA, Maule AG (2008) The silencing of cysteine proteases in Fasciola hepatica newly excysted juveniles using RNA interference reduces gut penetration. Int J Parasitol 38:149-155

McKeever DJ, Taracha EL, Innes EL, MacHugh ND, Awino E, Goddeeris BM, Morrison WI (1994) Adoptive transfer of immunity to Theileria parvain the CD8 + fraction of responding efferesnt lymph. Proc Nat Acad Sci USA 91:1959-1963

McKeever DJ, Taracha EL, Morrison WI, Musoke AJ, Morzaria SP (1999) Protective immune mechanisms against Theileria parva: evolution of vaccine development strategies. Parasitol Today 15:263267

McNamara JJ, Mohammed G, Gibson WC (1994) Trypanosoma (Nannomonas) godfreyisp. nov.from tsetse flies in The Gambia: biological and biochemical Characterization. Parasitol 109:497-509

McRobert L, McConkey GA (2002) RNA interference (RNAi) inhibits growth of Plasmodium falciparum. Mol Biochem Parasit 119(2): 273-278

Miller TA (1978) Industrial development and field use of the canine hookworm vaccine. Adv Parasitol 16:333-342

Mizuno T, Kanbayashi S, Okawa T, Maeda S, Okuda M (2009) Molecular cloning of canine interleukin-31 and its expression in various tissues. Vet Immunol Immunopathol 131(1-2):140-143

Morgan UM, Thompson RC (1998) Molecular detection of parasitic protozoa. Parasitol 117:73-85

Morrison WI, McKeever DJ (1998) Immunology of infections with Theileria parvain cattle. Chem Immunol 70:163-185

Muller N, Zimmermann V, Hentrich B, Gottstein B (1996) Diagnosis of Neosporacaninumand Toxoplasma gondiiinfection by PCR and DNA hybridisation immunoassay. J Clin Microbiol 34:2850-2852

Musoke A, Morzaria S, Nkonge C, Jones E, Nene V (1992) A recombinant sporozoites surface antigen of Theileria parvainduces protection in cattle. Proc Natl Acad Sci USA 89:514-518

Olomski F, Fettelschoss V, Jonsdottir S, Birkmann K, Thoms F, Marti E et al (2020) Interleukin 31 in insect bite hypersensitivity - alleviating clinical symptoms by active vaccination against itch. Allergy 75(4): 862-871. https://doi.org/10.1111/all.14145

Parizi LF, Githaka NW, Logullo C, Konnai S, Masuda A, Ohashi K, Itabajara da Silva Vaz Jr (2012a) The quest for a universal vaccine against ticks: Cross-immunity insights. The Vet Journal 4:5-12

Parizi LF, José Reck Jr, Oldigesa DP, Guizzoa MG, Seixasa A, Logullod C, Pedro L, de Oliveirae C, João TermignoniaC, Martinsb R (2012b) Multi-antigenic vaccine against the cattle tick. In: Itabajara da Silva Vaz Jr (ed) Rhipicephalus (Boophilus) microplus: A field evaluation. (e-Publication), Vaccine JR

Pipano E (1995) Live vaccines against hemoparasitic diseases in livestock. Vet Parasitol 57:213-231

Plancarte A, Flisser A, Gauci CG, Lightowlers MW (1999) Vaccination against Taeniasoliumcysticercosis in pigs using native and recombinant oncosphere antigens. Int J Parasitol 29:643-647

Preston PM, Hall FR, Glass EJ, Campbell JD, Darghouth MA, Ahmed JS, Shiels BR, Spooner RL, Jongejan F, Brown CG (1999) Innate and adaptive immune responses co-operate to protect cattle against Theileria annulata. Parasitol Today 15:268-274

Prudencio CR, de la Lastra JMP, Canales M, Villar M, de la Fuente J (2010) Mapping protective epitopes in the tick and mosquito subolesinortholog proteins. Vaccine 28:5398-5406

Rappuoli R (2000) Reverse vaccinology. Curr Opin Microbiol 3(5):445450

Rehman A, Jasmer DP (1999) Defined characteristics of cathepsin B-like proteins from nematodes: inferred functional diversity and phylogenetic relationships. Mol Biochem Parasitol 102:297-331 
Rezende AM, Folador EL, Resende DDM, Ruiz JC (2012) Computational prediction of protein-protein interactions in Leishmania predicted proteomes. PLoS One 7(12):513-524

Rinaldi G, Morales ME, Alrefaei YN, Cancela M, Castillo E, Dalton JP, Tort JF, Brindley PJ (2009) RNA interference targeting leucine aminopeptidase blocks hatching of Schistosoma mansoni eggs. Mol Biochem Parasitol 167:118-126

Rinaldi G, Morales ME, Cancela M, Castillo E, Brindley PJ, Tort JF (2008) Development of functional genomic tools in trematodes: RNA interference and luciferase reporter gene activity in Fasciola hepatica. PLoS Negl Trop Dis. https://doi.org/10.1371/journal.pntd. 0000260

Robinson KA, Beverley SM (2003) Improvements in transfection efficiency and tests of RNA interference (RNAi) approaches in the protozoan parasite Leishmania. Mol Biochem Parasitol 128(2): 217-228

Roy N, Nageshan RK, Pallavi R, Chakravarthy H, Chandran S, Kumar R, Gupta AK, Singh RK, Yadav SC, Tatu U (2010) Proteomics of Trypanosomaevansi infection in rodents. PLoS One 5(3)

Sánchez E, Perrone T, Recchimuzzi G, Cardozo I, Biteau N, Aso PM, Mijares A, Baltz T, Berthier D, Balzano-Nogueira L, Gonzatti MI (2015) Molecular characterization and classification of Trypanosoma spp. Venezuelan isolates based on microsatellite markers and kinetoplastmaxicircle genes. Parasites Vectors 8(1):536

Schnieder T, Heise M, Epe C (2010) Genus-specific PCR for the differentiation of eggs or larva from gastrointestinal nematodes of ruminants. Parasitol Res 85:895-898

Schubert-Unkmeir A, Christodoulides M (2013) Genome-based bacterial vaccines: current state and future outlook. Bio Drugs 27(5):419-430

Sette A, Rappuoli R (2010) Reverse vaccinology: developing vaccines in the era of genomics. Immunity 33(4):530-541

Sharifiyazdi H, Namazi F, Oryan A, Shahriari R, Razavi M (2012) Point mutations in the Theileria annulata cytochrome $\mathrm{b}$ gene is associated with buparvaquone treatment failure. Vet Parasitol 187(3-4):431435

Sharma A, Kaur P, Bal MS, Singla LD (2014) Application of multiplex PCR for the simultaneous detection of natural infection of theileriosis, babesiosis and trypanosomosis in cattle. J Vet Parasitol 28(2):112-116

Sharma P, Juyal PD, Singla LD, Chachra D, Pawar H (2012) Comparative evaluation of real time PCR assay with conventional parasitological techniques for diagnosis of Trypanosomaevansi in cattle and buffaloes. Vet Parasitol 190(3-4):375-382

Sharma RL, Dhar DN (1980) Attenuation of the ovine nodular worm, Oesophagostomumcolumbianum by gamma rays. Rivista di Parassitologia 41(2):235-240

Shiels BR, D’Oliveira C, McKellar S, Ben-Miled L, Kawazu S, Hide G (1995) Selection of diversity at putative glycosylation sites in the immunodominant merozoite/piroplasm surface antigen of Theileria parasites. Mol Biochem Parasitol 72:149-162

Shirley MW, Bedrnik P (1997) Live attenuated vaccines against Avian coccidiosis: success with precocious and egg-adapted lines of Eimeria. Parasitol Today 13:481-484

Skuce PJ, Stewart EM, Smith WD, Knox DP (1999) Cloning and characterization of glutamate dehydrogenase (GDH) from the gut of Haemonchuscontortus. Parasitol 118:297-304
Smith HV (1998) Detection of parasites in the environment. Parasitol 117:S113-S141

Smith TS, Graham M, Munn EA, Newton SE, Knox DP, Coadwell WJ, McMichael-Phillips D, Smith H, Smith WD, Oliver JJ (1997) Cloning and characterization of a microsomal aminopeptidase from the intestine of the nematode Haemonchuscontortus. Biochim Biophys Acta 1338:295-306

Sonkoly E, Muller A, Lauerma AI, Pivarcsi A, Soto H, Kemeny L et al (2006) IL-31: a new link between T cells and pruritus in atopic skin inflammation. J Allergy Clin Immunol 117(2):411-417

Sukarsih Partoutomo S, Wijffels G, Willadsen P (2000b) Vaccination trials in sheep againstChrysomyabezziana larvae using the recombinant pertirophin antigens $\mathrm{Cb} 15, \mathrm{Cb} 42$ and $\mathrm{Cb} 48$. Jurnal Ilmu Ternakdan Veteriner 5:192-196

Sumbria D, Singla LD, Sharma A (2016) Theileria equi and Babesia caballi infection of equids in Punjab, India: a serological and molecular survey. Trop Anim Health Pro 48(1):45-52

Talvik H, Christensen CM, Joachim A, Roepstorff A, Bjorn H, Nansen P (1997) Prepatent periods of different Oesophagostomumspp. isolates in experimentally infected pigs. Parasitol Res 83:563-568

Tellam RL, Vuocolo T, Eisemann C, Briscoe S, Riding G, Elvin C, Pearson R (2003) Identification of an immuno-protective mucin-like protein, peritrophin-55, from the peritrophic matrix of Luciliacuprina larvae. Insect Biochem Mol Biol 33(2):239-252

Thomas LF, Cook EA, Fèvre EM, Rushton J (2019) Control of Taeniasolium; a case for public and private sector investment. Front Vet Sci 6:176

Wang T, Zhao M, Rotgans BA, Strong A, Liang D, Ni G, Limpanont Y, Ramasoota P, McManus DP, Cummins SF (2016) Proteomic analysis of the Schistosoma mansonimiracidium. PloS one 11(1): 0147247

Willadsen P, Bird P, Cobon GS, Hungerford J (1995) Commercialisation of a recombinant vaccine against Boophilusmicroplus. Parasitol 110:43-50

Willadsen P, Jongejan F (1999) Immunology of the tick-host interaction and the control of ticks and tick-borne diseases. Parasitol Today 15: 258-262

Wright IG, Casu R, Commins MA, Dalrymple BP, Gale KR, Goodger BV, Riddles PW, Waltisbuhl DJ, Abetz I, Berrie DA (1992) The development of a recombinant Babesia vaccine. Vet Parasitol 44:3 13

Xiang Z, He Y (2013) Genome-wide prediction of vaccine targets for human herpes simplex viruses using Vaxign reverse vaccinology. BMC Bioinformat 14(4):S2

Yamage M, Flechtner O, Gottstein B (1996) Neosporin caninum: specific oligo nucleotide primers for the detection of brain cyst DNA of experimentally infected nude mice by the polymerase chain reaction (PCR). J Parasitol 82:272-279

Zarlenga DS, Chute MB, Martin A, Kapel CMO (1999) A multiplex PCR for unequivocal differentiation of all encapsulated and nonencapsulated genotypes of Trichinella. Int J Parasitol 29:1859-1867

Publisher's note Springer Nature remains neutral with regard to jurisdictional claims in published maps and institutional affiliations. 